\title{
"Sweet Dolly Sodam": Narrative Drag in Djuna Barnes's Ryder
}

\section{ANN MARTIN}

Ann Martin (arc_martin@hotmail.com) is a doctoral candidate at the University of Toronto in the Department of English. Stemming from issues raised in her dissertation, Red Riding Hood and the Wolf in Bed: Modernism's Fairy Tales, this article explores Barnes's presentation of gender performance according to her citations of canonical texts.

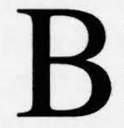

onnie Kime Scott has compared Ryder to the "Oxen of the Sun" chapter of James Joyce's Ulysses: "a nightmarish version of a graduate comprehensive exam" (159). Despite its loose sense of chronology, its convoluted and often disturbing storyline, its range of primary characters, and above all, its basis in "a succession of literary styles" (163), Djuna Barnes's first novel, published in New York in 1928, was a brief bestseller (see Herring 143; Kannenstine 33). Not surprisingly, the link Scott makes between Ryder and a male-centered literary canon is a prominent feature in contemporary evaluations of the novel. In her "Paris Letter," Genêt (a.k.a. Janet Flanner) compares Ryder to Robert Burton's Anatomy of Melancholy, pointing to the novel's "historical richness and tradition" (37). The reviewer C. D. F. from The Nation hears echoes of Laurence Sterne and Henry Fielding in Barnes's text (639). Ernest Sutherland Bates links Barnes to Aristophanes, Geoffrey Chaucer, William Shakespeare, and Ben Jonson (376). The reviewer L. B. in the New Republic points out the similarities between Barnes's writing and "the King James version" of the Bible (282).

These critics emphasize not just the "versatility" of Barnes's style (Bates 376), but also her "masculine approach" to writing (L. B. 282). Eugene Jolas actually suggests that the character of Wendell Ryder

torquere: Journal of the Canadian Lesbian and Gay Studies Association I Revue de la Société canadienne des études lesbiennes et gaies

Vol. 2 (2000) $\odot$ CLGSA / SCELG 


\section{$106 /$ Martin}

"will go down in American literature as the archetype of the swashbuckling super-male" (282). Barnes becomes the woman writer who writes with or as the best of the men. However, her use of different styles results not just in admiration, but also in confusion regarding the identity of the author and her status in the text. As a result, critics from the 1920 s to the present day attempt to locate Barnes in specific gendered positions as if to stabilize her shifting persona in Ryder. Such readings of Barnes and her novel are generally based on a series of binaries and focus on the significance of the disjunction between the masculine literary tradition and the woman who refers to it.

These critical reactions to Barnes's work relate to the gendering of the canon but also to the trope of writerly authority and readerly deference, where the woman and the reader have often been placed at the margins of the canonical text. By approximating the voices of venerable male authors, Barnes foregrounds the instability of such hierarchical and heterosexual approaches to literature. I propose, then, that an alternate way to figure Barnes's stylistic experimentation is based in the idea of narrative drag, a kind of literary cross-dressing that plays with the assumptions which inform traditional views of the canon. Barnes assumes the position of canonical male authors by appropriating aspects of their style, including diction, narrative structure, and imagery. She derives authority for her writing through her imitative references, where her critics relate the value of Ryder to the value of the writers and works to which she alludes. At the same time, her ironic performance of writerly identities results in a critique of the gendered system by which that value is erected. In this sense, Barnes does not 'pass' as the canonical male author; rather, she passes through this identity as well as the identities of narrator, illustrator, editor, and censor. Barnes presents in Ryder an excess of signification through a layered performance of personae that cannot be contained by the binaries of male or female, reader or writer, writer or editor, author or critic. The result is a reterritorialization of authority in her text - not a consolidation of textual control, but instead an indication of its provisionality.

The subversive potential of narrative drag relates to the literal cross-dressing that Barnes presents in her work. Barnes challenges the naturalized or originary status of the masculine literary tradition by foregrounding in her texts ways in which bodies and voices resist essentialist heterosexual signification. For example, Evangeline 
Musset in Ladies Almanack is described as having

been developed in the Womb of her most gentle Mother to be a Boy, when therefore, she came forth an Inch or so less than this, she paid no Heed to the Error, but donning a Vest of a superb Blister and Tooling, a Belcher for tippet and a pair of hip-boots with a scarlet channel ... she took her Whip in hand, calling her Pups about her, and so set out upon the Road of Destiny. (7)

In Nightwood, Robin Vote wears "boy's trousers" (169) and Doctor Matthew Mighty-Grain-of-Salt Dante O'Connor entertains an unexpected Nora Flood wearing makeup, a wig of "golden ... long pendent curls" and "a woman's flannel nightgown" (79). Doctor O'Connor also appears in Ryder where in chapter 32 he confesses to Father Lucas: 'I've done it again, and this time it was with Fat Liz, him as keeps bar in a gophered boudoir cap, and smelling all zig-zag of patchouli" (174). Signifiers are dislocated from their traditional signifieds in these examples. As Judith Butler points out, the dislocation of sexed body and sign of gender can work to expose "the failure of heterosexual regimes ever fully to legislate or contain their own ideals" (237). In the case of drag, or the incongruous appropriation of gender norms, this can produce what Marjorie Garber calls the "category crisis," or the "failure of definitional distinction" (16). The reader of the text of the body, faced with the challenge to gender boundaries, attempts to stabilize the slippage between signifier and signified and is thus tempted to look "through rather than at the cross-dresser ... to want instead to subsume that figure within one of the two traditional genders" (Garber 9).

Not surprisingly, the readers of Ryder tend to look through the text to its male-authored precursors, and thus rely on the binaric systems of male and female writing to situate Barnes and her work. Contemporary reviews indicate the anxiety that surrounds the apparently natural estate of masculine writing, an anxiety demonstrated in such ambiguous statements as " $R y d e r$ ' is certainly the most amazing book ever written by a woman" (Bates 376) and "a book that absolutely baffles classification, but surely is a most amazing thing to come from a woman's hand" (Calhoun 12). There is a certain amount of confusion in these reviews and it centers on Barnes's approximation of an apparently masculine style: how can a woman write in such a manly way? Of course, this is a question that the 


\section{8 / Martin}

reviewers cannot actually pose. Not only might it lead into a reconsideration of the terms 'man' and 'woman,' but it might also threaten the stability of the canon that is based on distinctions between the two. If there cannot be a norm without an abject or a center without a margin, then there cannot be masculine authors without what Jolas calls "feminine scribblers" (326). According to this logic, contemporary reviewers emphasize the gaps between Barnes's novel and the canonical texts from which she borrows. Her failure to assimilate the styles of her precursors - to embody the patriarchal norms of authorship - becomes a frequent theme. Thus, where the dust jacket of Ryder suggests that the novel can be read in terms of the picaresque, the reviewer C. D. F. from The Nation states that "it fails of the true picaresque quality" (639) and L. B. in the New Republic argues that Wendell Ryder "is hardly a picaresque figure" (282). On one hand, Barnes outperforms the men through the sheer excess of her stylistic references; on the other hand, she can never be the male writer. As a result, Barnes's approximation of the masculine voice in the novel is labeled as inauthentic.

Feminist critics argue, however, that Barnes's project is based precisely on this kind of incongruous imitation, where a masculine genre is subverted by Barnes's focus on the subject of women's experience. Sheryl Stevenson suggests that by casting Barnes as a masculine writer, reviewers have missed "the feminist direction" of her work and the fact that "Ryder is not derivative but analytic: a reseeing of carnivalesque writing from the woman's angle" ("Writing" 81). Marie Ponsot points out that the stylistic experimentation of Ryder allows Barnes not to avoid, but to address some of the realities of a domestic sphere: "childbed; rape; miscarriage; missed abortion; sexual activity wretched or pleasant; incest and threat of incest; vague implications of bestiality; child abuse" (111). The woman's world is thus presented in the man's style; the picaresque is seen through the other side of the mirror. Barnes's ironic deployment of the techniques of her precursors is thus more a critique than a celebration of patriarchy, wherein she demonstrates the failure of the father's text by examining the previously elided status of the $(\mathrm{m})$ Other.

One of the issues that arises from these readings is the heterosexism of the system according to which Ryder and its author are interpreted. Ryder has been read as if Barnes the woman is 'passing' as a man. This imitation has been viewed as an earnest if 
flawed citation in which Barnes is "a disciple of James Joyce and T. $\mathrm{S}$. Eliot" (Kannenstine $\mathrm{x}$ ). Alternately, it has been seen as an ironic move, where Ryder "mocks its oversexed, all-fathering hero and parodies numerous male writers" (Stevenson, "Contraception" 97). Both readings are restricted by the same system that informs the gendering of the canon, however, and I suggest that both are undercut by the excess of signification that Barnes's authorial cross-dressing involves. To borrow from Marjorie Garber, the power of the figure in drag "inheres in her blurred gender, in the fact of her cross-dressing, and not ... in either of her gendered identities" (6). According to her polyvalent position in Ryder, Barnes slips through a system where, on the one hand, the sense of the masculine canon depends on the nonsense of women writers, and on the other, the sense of women's writing depends on the nonsense of the masculine canon. Instead of focusing on making this kind of 'sense,' Barnes emphasizes how texts come to mean. She explores and challenges traditional views of maleauthored works by approximating various literary styles both seriously and parodically. Ryder becomes a novel that centers on the possibility of inferring meaning according to multiple and often conflicting positions of textual authority.

Narrative drag is thus a form of resistance where the author traverses identities and indicates the provisionality of control over his or her text. It is a strategy that can be linked to Monique Wittig's provocative reading of Barnes and her work:

Taken as a symbol or adopted by a political group, the text loses its polysemy, it becomes univocal ... Doubtless this is why Djuna Barnes dreaded that the lesbians should make her their writer, and that by doing this they should reduce her work to one dimension. (63)

I contend that Wittig's argument is ironic. She exposes significant aspects not only of Barnes's writing but of the ideology of the society into which that work was and is received. Though Barnes chose not to self-identify as a lesbian (see Field 101), her troubling of patriarchal paradigms indicates that what she rejects is not her sexuality, but rather the terms used to define it. In resisting definition, she resists the system into which she and her work would be placed, the system that labels the lesbian as one-dimensional, the system that assumes that language, narrative, and sexuality are all heterostable. Narrative drag is the way she subverts these assumptions, since the place of 


\section{$110 /$ Martin}

Barnes in the text shifts according to the gendered roles and voices that she adopts for herself.

Barnes plays most overtly with these different positions and voices in chapter 10 of Ryder,"The Occupations of Wendell." Wordplay becomes a key to Barnes's imitative strategy in this chapter, where she resists identification with any one position - gender or authorial - by emphasizing the provisionality of the language that defines such positions. Joseph Allen Boone has indicated that "Barnes's prose style is 'queer' in multiple senses, but particularly in its refusal of any easy coupling of the label and the labeled" (240). I relate this to Eve Kosofsky Sedgwick's suggestion of what "“queer' can refer to":

the open mesh of possibilities, gaps, overlaps, dissonances and resonances, lapses and excesses of meaning when the constituent elements of anyone's gender, of anyone's sexuality aren't made (or can't be made) to signify monolithically. (8)

The excesses of Barnes's writing foreground the performative nature of narrative as well as the discursive status of the named and sexed body. Barnes challenges the patriarchal guarantee of the Symbolic in chapter 10 of Ryder by estranging words from their contexts and by undercutting the assumption of stability that informs traditional readings of signs, especially in canonical literature. This strategy lies behind her ironic presentation of the act of naming, for instance, where the tension between sign and referent indicates the contingent nature of language. The biblical names of Wendell Ryder's cows echo his position as a new Adam who sets forth and multiplies by disseminating his philosophy of free love and by labeling the world he inhabits. The irony here, of course, is that it is Barnes who refigures the connection between world and word, and who redefines the relationship between signifier and signified. The names of the cows themselves - "Sweet Dolly Sodam" and "Gamorra" (71) - involve a range of referential contradictions and ironic possibilities, and point to a society that might be lived by the phallus but not necessarily governed by it. Are the allusions to Sodom and Gomorrah straight? Do they imply bestiality as well as sodomy? And is the farm, Bull's Ease, not a new Eden after all, but rather an abomination in the eyes of the Lord? Or is the impact of the religious allusions undercut by the Sweetness of Dolly, where sin is neutralized by childlike innocence or justified by enjoyment? The scene is further complicated by the ambiguous gender status of the two calves. While Andrew Field 
discusses how "Wendell's cows, Sweet Dolly Sodam and her twin Gamorra, are festooned with jewelry like his women" (184), Barnes's text also mentions that the cows have "newë waxen horns, more in than out" (71). The uncertainty of their sexual status is complicated by potentially conflicting signs of gender, just as the significance of their position in the text is complicated by Barnes's use of wordplay.

The anachronistic tone of the chapter is another way in which Barnes challenges the very idea of linguistic, gender, and textual stability. When Barnes approximates a medieval literary voice, she indicates that authorial identity is itself a fiction capable of being reinhabited and refigured. Similarly, the twentieth-century context of the Middle English signifiers affects the apparent stability of their signifieds. The archaic diction of chapter 10, its authenticity supposedly attested to by the footnotes she provides, thus highlights Barnes's playful use of language as well as of writerly personae. A notable example is the name of Wendell Ryder. The Middle English term "wend" - meaning to go, or "to make one's way" - is joined up with a seventeenth-century term "dell" - meaning "wench" - and coupled with a homonym for "rider," thus together emphasizing the central figure's sexual jaunts into the countryside. But Barnes does not just dabble in the language of medieval texts; she also parodies our expectations of the scholarly apparatuses that accompany modern editions of older literature. By including her own footnotes, she impersonates the identity of the academic as well as the writer and philologian. The combination of text and footnotes provides a minihistory of developments in the English language. The change from strong to weak verbs is signaled in the translation of "shope" as "Shaped" (70). Metathesis is figured when "brin" is glossed as "Burn" (77). Barnes indicates the shift in the position of negatives where "nold I falsen" is explained as "I will not lie" (68), and shows the etymological progressions of words such as "reck" which is footnoted as "Reckon, think of" (78). In addition to the Middle English diction, she defines scientific terms. For instance, "pylorus" is decribed as "Opening from stomach into duodenum" (81). Words are lent a medieval twist - the anachronism "tipë-toes" is an example - and some words whose meanings seem obvious are glossed unnecessarily: "erse" is explained as "Arse" (70) and "rashly" as "Hurriedly" (84). Correspondingly, terms that are not translated become open to interpretation. Is "villain" (74) intended to mean a simple rustic 


\section{2 / Martin}

character, a boor, or a perpetrator of evil deeds? Barnes pokes fun at the reader's reliance on the footnotes and so foregrounds the authority that the reader accords the editor. But the various gaps, inconsistencies, irrelevancies, and ironies undercut this apparent assertion of control over the meaning of words. Barnes's citation of authorial and editorial voices thus multiplies the levels of signification in the text and disrupts meaning instead of locating it according to the writer's identity.

The Middle English diction, rhyming pentameter, fifteenthcentury imagery, and layered narrative structure are what prompt critics to read Ryder as a Chaucerian work (see Field 183; Herring 141-42; Kannenstine 37; Scott 163; Stevenson, "Contraception" 97). In keeping with the irony and narrative structure of Barnes's chapter, I suggest the more specific intertext is Geoffrey Chaucer's "Tale of Sir Thopas" from The Canterbury Tales. It is the ambiguity of Barnes's approximation of Chaucer's identity that results in much of the critical confusion that surrounds Ryder. One of the reasons is that narrative drag, like irony, is based on an "intimacy with the dominant discourses it contests" (Hutcheon 30). Barnes cites not just Chaucer's work but, inevitably, his status and prestige. As Carolyn Dinshaw notes, Chaucer's poetry "has come in the anglophone West to signify Literature itself" (80). His stature and his influence are attested to by the reviewers who point out that the Chaucerian style is a strength in the novel. At the same time the significance of Chaucer, or rather the hegemonic norm of literary masculinity that Chaucer represents in the canon, becomes reterritorialized when Barnes, a twentieth-century woman writer, performs his voice and persona.

The fact that Barnes uses Chaucer's work and style in Ryder signals her challenge to the naturalization of the canonical text as masculine. Not only does she imitate Chaucer's voice; she imitates his narrative structure and the content of his tale. "The Occupation of Wendell" and Chaucer's "Tale of Sir Thopas" share a similar diction, a similar rhyme scheme, a mise-en-abîme structure, and multiple levels of narrative control. In terms of content, both texts center on a romantic figure, Sir Thopas and Wendell Ryder respectively. Both men even venture out into the world riding large horses. But where Chaucer-the-naive-narrator focuses on the piously romantic aspects of his hero, Barnes focuses on the bodily realities of hers. Where Sir Thopas dreams of "An elf-queene" and decides that "in this world no womman is / Worthy to be my make" (214), 
Wendell Ryder has two wives at home and ventures into the countryside to "wench - where he could" (69). Where Sir Thopas is armed with "a launcegay" and "A long swerd by his side" (214), Wendell Ryder carries on his "pommel" a "sponge" for postcoital cleansing (77).

Barnes's hypermasculine refiguration of Chaucer's hero is obviously an ironic commentary on the gendering and performative nature of literary voice. However, she also explores issues in "The Occupations of Wendell" that Chaucer presents in his own texts, especially surrounding the apparently stable and reliable position of the author. In this sense, Barnes's parody of the romance hero pertains to Chaucer's own parody of the romance genre. This shared satirical intent is enabled by the multiple levels of narration in both works which produce sites of irony and disrupt the reader's sense of the writer's place in the text. In The Canterbury Tales, Chaucer-the-author frames Chaucer-the-naive-narrator who introduces and tells the romance of Sir Thopas. In chapter 10 of Ryder, Barnes-the-author frames Barnes-the-naive-narrator who comments upon and frames Wendell Ryder's tale of Pennyfinder the Bull. This layering leads to the self-reflexive commentary present in both authors' works. Chaucer-the-narrator's performance of an unsophisticated minstrel romance is a parody of bad poetry, signaled when the Host of the Inn where the pilgrims have stayed stops the tale and tells its narrator that "Thy drasty rymyng is nat worth a toord!" (216). Chaucer's selfdramatization in the scene allows him to present an ironic judgment of his own recitation of The Canterbury Tales, and thus to satirize the writer's authority over his clearly hostile audience. In a similar move, Barnes indicates her awareness of the difficulty that the language of chapter 10 poses to her reader, first by inserting footnotes to explain the diction, and second by naming chapter 11 , written in straightforward prose, "However, for the Reader's Benefit" (86). Like Chaucer, Barnes emphasizes through irony the limits of textual authority according to the position of the writer and reader in question.

A traditional interpretation of Barnes's allusions to Chaucer's text would maintain that the author, style, and structure of Ryder indicate a series of incongruous imitations: a modernist mimics a medievalist, a woman novelist models her work on a male poet, a marginalized lesbian writer emulates a canonical heterosexual author. While the obvious discrepancies among these identities inform 


\section{4 / Martin}

Barnes's subversive use of his style and subject, more recent readings of Chaucer indicate the queer aspects of his work and trouble conventional views of his presentation of sexuality. These are aspects of Chaucer's writing that I suspect Barnes recognized in her use of the "Tale of Sir Thopas." Barnes does not just borrow Chaucer's irony or narrative structure; she also capitalizes on the gender confusion that surrounds The Canterbury Tales. In this sense, the Chaucer she cites in her literary cross-dressing is not only that seminal figure in the history of Western literature, but also an author who himself represents a challenge to heterosexual readings of canonical works.

Chaucer's examination of 'othered' sexualities is connected most often to his depiction of the Pardoner, whom Chaucer-the-narrator describes as "a geldynge or a mare" (34). The "feminized" body of the Pardoner is subsequently linked to the "wayward" nature of his spiraling tale (Burger 161-62). His slippery performance of both gender and narrative is, however, cut short by the Host's violent interruption, an interruption which Steven Kruger reads as an indication of "the violent force needed to contain the queer" (138). In an echo of that interruption, Chaucer-the-narrator's "Tale of Sir Thopas" is also halted by the Host. The Host's policing of the narratives relates to his policing of the bodies of Chaucer and the Pardoner, where text and voice must be identified as properly masculine in order to signify. Chaucer-the-narrator is presented, like the Pardoner, as an insufficiently masculine man. He is described by the Host as "smal and fair of face," a man who "seemeth elvyssh by his countenaunce" (213). The daintiness of this Chaucer and the otherness that he embodies place him as a far less threatening version of the Pardoner. Thus "the "father of English poetry"' (Burger 160) becomes no longer a man but instead a doll: "a popet in an arm t'enbrace / For any womman" (Chaucer 213).

I suggest that Barnes is the woman who embraces the possibilities that these episodes and their author present. To use Judith Butler's phrase, both Barnes and Chaucer question "heterosexuality's claim on naturalness and originality" (125). They both present and approximate positions that are labeled as abject and indicate the ways in which such identities are policed according to cultural normatives. Chaucer signals the discursive and performative nature of gender by emphasizing the Host's power over both the Pardoner and Chaucer- 
the-narrator, and thus signals the instability of a system that needs such policing. However, he also reasserts the power of the Symbolic order in his presentation of the issue. As the authority behind his text, Chaucer has the father figure of the Knight, for example, force the Pardoner and the Host to kiss as brothers. In contrast, Barnes resists such closure and focuses on how the law is undercut even where it is cited when she inhabits the position of Chaucer. As a woman, Barnes becomes an ironic embodiment of Chaucer's "effeminate" textual persona (Burger 160) and her narration emphasizes the instability of gendered authorial identity. At the same time, she indicates the limits to her performance of and control over that voice by alluding to the "Tale of Sir Thopas" and to the Host's impatience with inauthentic narratives and inaccurate portrayals of gender. Ironically, it is an allusion that foreshadows the reception of her work by contemporary reviewers. By playing with the possibilities of Chaucer's voice and text and by expanding upon their significance, Barnes produces neither a feminist condemnation of Chaucer, nor a straight imitation of his style, but a combination of the two that undercuts univocal interpretation. Like the juxtaposition of verse and footnotes, or the combination of narrative voices, the multiple layers of textual authority and the slipperiness of the gender of the narrator confound a search for the writer who will guarantee the significance of the text, or who will pin down the meaning based on his or her sexual or canonical identity.

Where Barnes signals her use of Chaucer's voice and text by approximating his distinctive style, her use of narrative drag elsewhere in "The Occupations of Wendell" is less overt. Even so, it connects both to Barnes's focus on the process of interpretation, as well as to the possibility of reading resistantly those works and authors she cites. In her own text, this relates to the multiple layers of signification which challenge the binaric hierarchy of writer and reader. Lewis Carroll's Through the Looking-Glass becomes an important story in the chapter for this reason, especially in terms of Alice's encounters with the slipperiness of language and with the often threatening figures of adult authority. Carroll's overtly satirical presentation of literary classics and of scholarly exegesis connects to Barnes's ironic performance of Chaucerian diction and academic footnoting. The significance of the male-authored canonical text and of Chaucer's influence on Ryder is also undercut by Barnes's use of popular 


\section{$116 /$ Martin}

children's literature. Barnes alludes specifically to Alice who "went in Wonderland astound" (69), where the girl's journeys ironically reflect both the travels that Wendell Ryder makes in the New York countryside, as well as Sir Thopas's abbreviated quest in Chaucer's romance. The allusion to Alice thus provides another view of the romance hero, here an identity that is approximated by a young woman.

Barnes's literary cross-dressing in Ryder revolves primarily around Carroll's parody of scholarly inquiry and his challenge to assumptions regarding the transparency of language. Like Carroll, Barnes hinders and thus critiques the process of literary interpretation with her use of unstable language, where sliding frames of reference disconnect signifiers from their usual signifieds. Her play with anachronistic diction echoes her interest in double entendre and puns, where language becomes estranged according to a shift in context and is thus opened to the wider inference of meaning. Similarly, in Through the Looking-Glass, Carroll foregrounds the vagaries of the English language when Alice is forced to grapple with new terminology in order to negotiate the Looking-glass World. For example, instead of the metaphorical Butterfly, she is introduced to the literal Bread-and-butter-fly: "its wings are thin slices of bread and butter, its body is a crust, and its head is a lump of sugar" (Carroll 160). Alice also struggles to make sense of the diction of "Jabberwocky," the epic poem that she finds in a Looking-glass book. The archaic nature of the text relates obviously to Barnes's own chapter, and Alice's attempts to decipher its form and language mirror the reader's experience with Ryder. While Alice gathers from her reading that "somebody killed something" (Carroll 142), the language makes little sense. Eventually, Alice asks Humpty Dumpty to explain the content of the words to her; but instead of stabilizing meaning, his textual commentary indicates the duplicity of language: "Well, 'slithy' means 'lithe and slimy.' 'Lithe' is the same as 'active.' You see it's like a portmanteau - there are two meanings packed up into one word" (Carroll 198). Like the figure in drag, two signifiers are combined in one term, and that term is more than the sum of its parts. Humpty Dumpty's analysis leaves Alice unsettled and frustrated because of the excess of signification signaled by the portmanteau nature of language. The meaning of the word overflows the boundaries that are erected in order to contain it. Thus the interpretation and the 
authority figure who provides it are deemed "unsatisfactory" (Carroll 203).

Barnes echoes Carroll's parody of the academic pedant in her use of archaic diction and subversive footnotes and, like Carroll, stresses the confrontation between the reader and the text. Both authors attempt to satirize the gendered hierarchy of scholar and student. But where Barnes capitalizes on the subversive potential of Carroll's writing, she also remains at a critical distance from the position of authority that Carroll assumes in his text, especially as it relates to his construction of Alice. Carroll uses the youth and innocence of Alice to critique the absurdity of the grown-up world and the pomposity of adults like Humpty Dumpty or the Red Queen. At the same time, however, Alice is marginalized throughout the text, abjected by the characters but also by the author himself in his Preface to the story. Thus, while Carroll satirizes the figure of Humpty Dumpty whose control over language is linked to vanity, Carroll's own control over the main character of his text relates him to those adult figures who maneuver Alice through the story like a chesspiece.

Barnes explores some of the ramifications of Carroll's use of Alice through the character of Wendell Ryder. The two men are implicitly compared according to imagery surrounding the game of chess and the deck of cards, and according to their use of children. Ryder is the father figure who is likened to a gambler in his desire for children: "Nowise he was content till fifty-two / Were shapen each to go as cardës do" (Barnes 68). The sons and daughters that are produced by Wendell and the women of his world are figured as pawns in a patriarchal society, their lives determined by forces beyond their control. They will for "many a yearës round -/As Alice went in Wonderland astound, - / Play on the earthës checkerboard a pace, / Till death y-kiken long into their face. / And in the wrath of sleep, put forth her claw / And draw them in, to play not anymore" (Barnes 69). Here Barnes alludes specifically to Alice's position as a chesspiece in the Red Queen's chessboard garden, where she says "I wouldn't mind being a Pawn, if only I might join" (150). More importantly, Barnes indicates the fiction of Alice's autonomy and independence in Through the Looking-Glass by referring to the social reality that Wendell Ryder's children experience. Instead of Carroll's presentation of Alice as an active and powerful figure, Barnes points to the girl's lack of agency and lack of voice both in the world of fiction and in 


\section{$118 /$ Martin}

the everyday world.

Here, Barnes's citation of Carroll and his work relates to the process by which his authority as the writer is naturalized in his text. The Preface of Through the Looking-Glass represents a subtle 'othering' of the female child according to which Carroll assumes a position of privilege. The first lines establish Alice's significance in the text by establishing her relation to the author: "Child of the pure unclouded brow / And dreaming eyes of wonder! / Though time be fleet, and I and thou / Are half a life asunder, / Thy loving smile will surely hail / The love-gift of a fairy-tale" (Carroll 123). Alice is situated as the innocent and naive child to whom the older and wiser author directs his narrative. Carroll's power is asserted before the story even starts, according to this description of the child-as-reader, and according to his scripting of her exemplary reaction to his work. Like his pseudonym, the Preface indicates Carroll's control over his textual identity, here established according to hierarchical binaries: male and female, author and audience, old and young. Barnes's performance of Carroll's privilege as the writer thus undercuts these binaries. Djuna Barnes reflects the gender and social status of Alice, or Alice Liddel, more than she reflects the position of Lewis Carroll, or rather Charles Dodgson. The female reader against whom Carroll establishes his authority in the Preface comes to inhabit the position of the writer. In effect, Barnes refigures Carroll's challenge to Humpty Dumpty's authority by turning the critique upon Carroll himself. She thus makes explicit the performative nature of the masculine narrative by emphasizing the marginalized audience that guarantees its naturalized status and by inhabiting the position of power herself.

Barnes's Foreword to Ryder stands in contrast to Carroll's assertion of authorial control in his Preface to Through the LookingGlass. Where Carroll's story will be received by a smiling, inexperienced girl, Barnes's novel has already been received by her publishing company. Barnes was required to make substantial changes to Ryder by Liveright, and the Foreword stands as a testimony to the role of censorship in the publication of the novel. It indicates the limits of Barnes's authority over the text and over its audience, where her status as the writer is undercut by the power of her editors. For instance, several of Barnes's illustrations were deemed "too risqué" for Liveright and were viewed as a threat to sales (Herring 142). Barnes and her editor, Donald Friede, also cut a number of textual 
passages from Ryder, especially those dealing with sex and with "bodily fluids" (Field 127). But where text was deleted from the novel, Barnes inserted asterisks to indicate the effects of censorship. While she associates this act with "the better part of valour" (Barnes, Ryder $\mathrm{xi}$ ), the asterisks, along with the prefatory material, act as visual cues, indicating the disruption of narrative logic that accompanies the censorship, and highlighting the tension between the author's vision of the text and the version approved by the publishing company. As Barnes states in her Foreword:

Hithertofore the public has been offered literature only after it was no longer literature. Or so murdered and so discreetly bound in linens that those regarding it have seldom, if ever, been aware, or discovered, that that which they took for an original was indeed a reconstruction.

In the case of Ryder they are permitted to see the havoc of this nicety, and what its effects are on the work of the imagination. (xi)

Barnes's reference to the "original" work of literature and to its "reconstruction" becomes ironic in the context of her performance of other literary voices in the text. Again, she traverses identities, where she not only approximates the styles of various male authors but recognizes that her own work has been approximated in the publishing process. And though Barnes inhabits the position of the censored writer, she also editorializes that censorship in her text. Thus, while the Foreword indicates the provisionality of the writer's authority, it also asserts the limits of textual control on the part of the editor.

As a commentary on the act of censorship, which Barnes suggests is "as indiscriminate as all such enforcements of law must be" (xi), the Foreword links two very different novels of 1928, Ryder and Radclyffe Hall's The Well of Loneliness. But where the latter was banned in England for its depiction of "inversion" (see Brittain 89), the former was published by the American Liveright despite its 'licentious' depiction of bodies. The density of Barnes's narrative and its experimental nature may have obscured much of the 'immoral' content of the novel. Certainly, the language of Ryder caused some confusion for the censors. In June of 1928, for example, the U. S. Post Office held up distribution of the novel in order to examine in more detail the Chaucerian language of "The Occupations of Wendell" 
(see Herring 142). More important than its complex style, however, is the fact that the intertexts of Ryder and the literary techniques that Barnes cites are coded as masculine. Barnes's approximation of voices from the canonical literary tradition results in the novel being read according to its presentation of heterosexual bawdiness. As a result of looking through rather than at Barnes's narrative, the gaze of the censor, like the eye of the reviewer, appears to have been drawn toward the stability of the straight aspects of the text rather than to Barnes's references to gay, lesbian, and 'othered' sites of sexuality. The political significance of Ryder is thus limited according to its ambiguous citation of literary voices, where the efficacy of the text's presentation of queer sites of identity depends on the position of the reader. Nevertheless, Barnes's invocation of a range of apparently incongruous styles indicates her resistance to the law which polices texts and imitations of texts, as well as gender and the performance of gender, according to heterosexual paradigms of value.

Barnes emphasizes the discursive nature of authorial identity in her citation of male-authored works, where narrative performance becomes linked to gender performance in the context of her deployment of the canon. One of the effects of her narrative drag in Ryder, then, is to foreground the process of textual production and reception that results in the naturalized and originary status of the masculine literary tradition. Barnes challenges the stability of this textual gendering by challenging the stability of authorial identity and control. She presents a range of apparently conflicting voices where she assumes the persona of Chaucer's narrator, critiques the gendered power dynamics of Carroll's work, reterritorializes the signifiers of Middle English, and footnotes her own diction. In the context of the editing of Ryder, Barnes emphasizes and protests the censorship of her novel in her Foreword, and affirms both her authority and its limits. Barnes's negotiations with authorial identity, and her assertion and abdication of authority, result in a novel based on instability and on confounded hierarchical oppositions. Ryder becomes a text that, according to its author's ambiguous position, calls out for interpretational certainty, for policing by reviewers, by censors, and by well-meaning readers. 


\section{Works Cited}

Barnes, Djuna. Ladies Almanack. Normal, IL: Dalkey, 1992.

—. Nightwood. New York: New Directions, 1961.

—. Ryder. New York: Liveright, 1928.

Bates, Ernest Sutherland. “A Robust Tale.” Rev. of Ryder, by Djuna Barnes. Saturday Review of Literature 17 Nov. 1928: 376.

Boone, Joseph Allen. Libidinal Currents: Sexuality and the Shaping of Modernism. Chicago: University of Chicago Press, 1998.

Brittain, Vera. Radclyffe Hall: A Case of Obscenity? London: Femina, 1968.

Burger, Glenn. "Queer Chaucer." English Studies in Canada 20 (1994): 153-70.

Butler, Judith. Bodies that Matter: On the Discursive Limits of "Sex." New York: Routledge, 1993.

Calhoun, L. “A Woman's Hero.” The Argonaut. CIV (1 Sept. 1928)

12. Rpt. in Douglas Messerli, Djuna Barnes: A Bibliography. New York: David Lewis, 1975. 95.

Carroll, Lewis [Charles Lutwidge Dodgson]. Through the LookingGlass, and What Alice Found There. The Complete Works of Lewis Carroll. London: Penguin, 1988. 121-250.

C. D. F. "Fiction Shorts." Rev. of Ryder, by Djuna Barnes. The Nation 5 Dec. 1928: 639.

Chaucer, Geoffrey. The Canterbury Tales. The Riverside Chaucer. Ed. Larry D. Benson. Boston: Houghton, 1987.

Dinshaw, Carolyn. "Chaucer's Queer Touches / A Queer Touches Chaucer.” Exemplaria 7.1 (1995): 75-92.

Field, Andrew. Djuna: The Life and Times of Djuna Barnes. New York: Putnam's, 1983.

Garber, Marjorie. Vested Interests: Cross-Dressing and Cultural Anxiety. New York: Routledge, 1997.

Genêt [Janet Flanner]. "Paris Letter." The New Yorker 24 Dec. 1927: 35-37.

Herring, Phillip. Djuna: The Life and Work of Djuna Barnes. New York: Penguin, 1996.

Hutcheon, Linda. Irony's Edge: The Theory and Politics of Irony. London: Routledge, 1994.

Jolas, Eugene. "Glossary.” Transition 16-17 (1929): 326.

Kannenstine, Louis. The Art of Djuna Barnes: Duality and 
Damnation. New York: New York University Press, 1977.

Kruger, Steven. "Claiming the Pardoner: Toward a Gay Reading of Chaucer's Pardoner's Tale." Exemplaria 6 (1994): 15-39.

L. B. Rev. of Ryder, by Djuna Barnes. New Republic 24 Oct. 1928: 282.

Ponsot, Marie. “A Reader's Ryder.” Silence and Power: A Reevalutation of Djuna Barnes. Ed. Mary Lynn Broe. Carbondale: Southern Illinois University Press, 1991. 94-112.

Scott, Bonnie Kime. " "The Look in the Throat of a Stricken Animal': Joyce as Met by Djuna Barnes." Joyce Studies Annual 2 (1991): 153-76.

Sedgwick, Eve Kosofsky. Tendencies. Durham: Duke University Press, 1993.

Stevenson, Sheryl. "Ryder as Contraception: Barnes v. the Reproduction of Mothering." Review of Contemporary Fiction 13.3 (1993): 97-106.

—. "Writing the Grotesque Body: Djuna Barnes' Carnival Parody." Silence and Power: A Reevaluation of Djuna Barnes. Ed. Mary Lynn Broe. Carbondale: Southern Illinois University Press, 1991. 81-91.

Wittig, Monique. "The Point of View: Universal or Particular?" The Straight Mind and Other Essays. Boston: Beacon, 1992. 59-67. 